\title{
Pengembangan Bahan Ajar Elektronik Energi dan Momentum Terintegrasi STEM Untuk Meningkatkan Hasil Belajar Siswa SMA
}

\author{
Yuni Fitria \& Asrizal* \\ Pendidikan Fisika, Universitas Negeri Padang \\ *Email: asrizal@fmipa.unp.ac.id
}

Received: 2 Oktober 2021; Accepted: 16 November 2021; Published: 26 November 2021 DOI: http://dx.doi.org/10.29303/jpft.v7i2.3001

\begin{abstract}
Industrial revolution 4.0 makes a major contribution to life. The era of the industrial revolution 4.0 requires human resources that can compete in the global economy. STEM education plays an important role in increasing students' creativity to compete in the future. The facts found in the field, activities that support student creativity in learning have not been carried out properly. The teaching materials used have not improved student learning outcomes optimally. The solution to overcome these problems was to develop STEM-integrated electronic teaching materials. This research method was Research and Development $(R \& D)$. This study aims to determine the effectiveness of STEM integrated electronic teaching materials. Test the effectiveness of teaching materials using experiments beforeafter conducted in one experimental class. The significance of the effectiveness of using electronic teaching materials on learning outcomes was analyzed by normality test, homogeneity test, and t-test. Based on the data analysis, it was concluded that STEM integrated electronic teaching materials were effectively used in physics learning to improve the learning outcomes of $X$ grade students.
\end{abstract}

Keywords: Bahan Ajar Elektronik; STEM; Hasil Belajar

\section{PENDAHULUAN}

Revolusi industri 4.0 memberikan kontribusi besar dalam kehidupan. Pesatnya perkembangan ilmu pengetahuan dan teknologi nyata dampaknya, baik itu dibidang ekonomi, kebudayaan, politik, seni sampai ke dunia pendidikan. Dunia pendidikan dituntut untuk mengikuti perkembangan teknologi, serta dapat memanfaatkan teknologi (Singgih,

Dewantari, \& Suryandari, 2020). Salah satu upaya yang dilakukan dengan memfasilitasi dan menyediakan sumber-sumber belajar berbasis teknologi, sehingga dapat menghasilkan lulusan yang berkompeten sesuai dengan tuntutan pasar global (Lestari, Astuti, \& Darsono, 2018). Bekal yang diperlukan dalam menghadapi persaingan global adalah pendidikan STEM (Roehrig et al, 2021).

Pendidikan STEM berperan penting dalam meningkatkan kualitas sumber daya manusia (SDM) untuk mengikuti persaingan ekonomi global. Dalam dunia pendidikan integrasi aspek-aspek STEM dapat memberikan dampak positif terhadap peningkatan kompetensi dan hasil belajar siswa (Wahano, Lin, and Chang, 2020). Kompetensi ini perlu dimiliki siswa dalam bersaing di masa mendatang (Izzati et al, 2019). Salah satu upaya yang dilakukan yaitu menyediakan sumber belajar yang bermutu seperti bahan ajar (Wibowo \& Pratiwi, 2018).

Pentingnya bahan ajar menentukan proses pembelajaran yang berkualitas (Fitria \& Idriyeni, 2017). Pembelajaran di sekolah dapat didukung dengan menggunakan bahan ajar elektronik (Hustarna \& Melati, 2019). Bahan ajar elektronik dapat membantu siswa dalam memahami materi pembelajaran. Oleh karena itu, materi tersebut harus dikemas dengan tampilan menarik seperti bahan ajar elektronik fisika ( Ramdani et al, 2021).

Namun, kondisi nyata yang ditemukan di SMA Negeri 1 Gunuang Omeh tidak 
sesuai dengan kondisi ideal yang diharapkan. Kondisi nyata tersebut ditemukan setelah dilakukan studi pendahuluan. Studi pendahuluan yang dilakukan berkenaan dengan ketersediaan bahan ajar dan hasil belajar siswa. Kondisi nyata yang pertama berdasarkan hasil wawancara dengan guru fisika di SMAN 1 Gunuang Omeh yaitu bahan ajar yang digunakan masih dalam bentuk cetak seperti buku teks. Hambatan yang ditemui saat menggunakan bahan ajar ini adalah siswa kesulitan dalam memahami materi pembelajaran, cenderung bosan, dan kurang mengembangkan kreativitas yang dimiliki siswa. Disamping itu bahan ajar cetak membutuhkan biaya yang cukup mahal dalam pengadaanya. Guru membutuhkan bahan ajar yang lebih murah, menarik, dan memudahkan siswa dalam memahami materi pembelajaran.

Kondisi nyata kedua berkenaan dengan integrasi STEM dalam bahan ajar yang digunakan sekolah. Aspek STEM yang yang dianalisis pada bahan ajar meliputi integrasi sains, teknologi, teknik, dan matematika. Instrumen yang digunakan yaitu lembar analisis integrasi STEM pada bahan ajar. Rata-rata integrasi STEM dalam bahan ajar adalah 42,75. Hal ini menunjukan bahwa kurangnya pengintegrasian STEM pada bahan ajar, sehingga perlu tindak lanjut dalam mengintegrasikan STEM ke dalam bahan ajar.

Kondisi nyata yang ketiga yaitu hasil belajar siswa kelas X SMA Negeri 1 Gunuang Omeh. Rata-rata hasil ujian akhir semester (UAS) satu siswa kelas X MIPA dari 28 siswa yaitu 57,28. Berdasarkan KKM yang telah ditetapkan didapatkan 5 orang siswa yang tuntas. Hal ini menunjukan bahwa hasil belajar siswa dalam kategori cukup, sehingga belum sesuai dengan harapan.

Kondisi nyata yang keempat yaitu alasan memilih materi energi dan momentum. Alasan pertama, materi energi dan momentum akan lebih mudah dipahami jika menggunakan bahan ajar elektronik dan pendekatan STEM. Alasan kedua, persentase siswa SMA/MA negeri dan swasta yang menjawab benar dalam ujian nasional beberapa tahun terakhir. Persentase siswa yang menjawab benar dalam ujian nasional tahun 2017 sampai 2019 pada materi energi dan momentum adalah 45,50\% dan 42,33\%. Hal ini menunjukan bahwa persentase siswa yang menjawab benar pada materi energi dan momentum berada dalam kriteria kurang, sehingga belum sesuai dengan yang diharapkan.

Hasil studi awal yang didapatkan menunjukan kesenjangan antara kondisi nyata dan ideal. Kondisi nyata menunjukan bahwa guru masih membutuhkan bahan ajar yang menarik, mudah dipahami, dan murah untuk menunjang proses belajar mengajar, serta kurangnya pengintegrasian STEM dalam bahan ajar fisika. Disamping itu terlihat dari hasil belajar siswa yang belum sesuai dengan harapan. Permasalahan ini akan berdampak kepada kompetensi siswa dalam menghadapi era revolusi 4.0.

Solusi yang diberikan yaitu mengembangkan bahan ajar elektronik terintegrasi STEM menggunakan Flip Pdf Professional. Bahan ajar elektronik ini dikembangkan dengan tampilan menarik dan mudah dipahami. Bahan ajar elektronik lebih murah dan dapat diakses kapan saja. Hal tersebut diharapkan dapat meningkatkan pemahaman siswa terhadap materi yang diajarkan, di samping itu siswa dapat belajar secara mandiri (Lin, Chen, and Liu, 2017). Selain itu bahan ajar yang digunakan juga terintegrasi STEM, sehingga siswa dapat belajar dengan berbagai disiplin ilmu (Winarni, Zubaidah, \& Supriyono, 2016).

Bahan ajar merupakan seperangkat bahan/alat yang digunakan guru tersusun secara sistematis dalam mengajar (Kelana \& 
Pratama, 2019). Bahan ajar merupakan salah satu media bagi guru untuk melaksanakan perannya dalam proses pembelajaran (Asrizal, Festiyed, \& Sumarmin, 2017). Bahan ajar elektronik yaitu bahan ajar yang isi materinya dimuat dalam bentuk elektronik, baik itu berupa audio, audio visual maupun media interaktif (Sriwahyuni, Risdianto, \& Johan, 2019). Bahan ajar elektronik menampilkan kompetensi yang harus dikuasai siswa dalam pembelajaran (Riwu, Laksana, \& Dhiu, 2018).

Aplikasi Flip Pdf Professional merupakan aplikasi pembuat buku elektronik kaya fitur (Seruni, Munawaoh, Kurniadewi, and Nurjayadi, 2019). Kelebihan dari aplikasi ini yaitu dapat disisipkan kontenkonten multimedia seperti audio, animasi, teks, video, dan flash. Di samping itu, bahan ajar elektronik dapat dibolak-balik layaknya buku 3D, mudah dioperasikan di laptop dan mobile device. Hasil akhir dari produk yang dibuat menggunakan Flip Pdf Professional bisa di simpan ke dalam berbagai format seperti html, exe, zip, mobile version dan lain-lain (Kustijono \& Watin, 2017). Bahan ajar menggunakan Flip Pdf Professional dapat memudahkan siswa dalam belajar (Sriwahyuni, Risdianto, \& Johan, 2019).

STEM merupakan suatu pembelajaran terintegrasi antara science, technology, engineering, dan mathematics untuk mengembangakan kreativitas siswa dalam menyelesaikan masalah pada kehidupan sehari-hari (Winarni, Zubaidah, \& Supriyono, 2016). Science, technology, engineering, dan mathematics memiliki hubungan yang erat (NRC, 2014). Science menjelaskan keberadaan, hukum, dan prinsip suatu objek dan peristiwa, serta hubungannya. Technology berkembang dari hasil penelitian ilmiah. Engineering merupakan rekayasa yang menghasilkan teknologi untuk memecahkan masalah. Mathematics diperlukan untuk membuktikan dan mendefinisikan hukum atau prinsip dalam merancang dan mengembangkan teknologi (Capraro \& Morhan, 2013).

Penerapan STEM memberikan dampak positif terhadap hasil belajar (Lestari, Astuti, \& Darsono, 2018) (Simmarmata, et al, 2020). Hasil belajar merupakan perkembangan atau kemajuan siswa setelah mengikuti proses pembelajaran (Mirdanda, 2018). Penilaian hasil belajar peserta didik meliputi aspek sikap, pengetahuan, dan keterampilan (Winarni, Zubaidah, \& Supriyono, 2016). Bahan ajar berbasis STEM efektif untuk meningkatkan hasil belajar siswa pada aspek sikap, pengetahuan, dan keterampilan (Izzah, N., Asrizal, \& Festiyed, 2021). Bahan ajar berbasis STEM dapat meningkatkan pemahaman konsep siswa yang ditandai dengan peningkatan pretest dan posttest siswa (Pangesti, Yulianti, \& Sugianto, 2017).

Karakteristik seseorang yang lulusan STEM sangat dibutuh dalam dunia kerja (Britain, 2012). Penerapan pendidikan STEM dapat mengembangkan proses berpikir ilmiah siswa terhadap permasalahan yang harus dipecahkan serta memperoleh keterampilan dalam mengaplikasikan pengetahuan ilmiah yang dimiliki (Mustafa et al, 2016). Pendidikan STEM juga diperlukan untuk menumbuhkan keterampilan seperti pembinaan literasi mata pelajaran STEM (Yata, Ohtani, \& Isobe, 2020)

\section{METODE PENELITIAN}

Penelitian ini menerapkan metode penelitian dan pengembangan (Research and Development / R\&D) (Sugiyono, 2012). Penelitian ini menghasilkan produk bahan ajar elektronik energi dan momentum terintegrasi STEM dengan Flip Pdf Professional untuk meningkatkan hasil belajar siswa kelas X SMA. Prosedur pada penelitian ini menggunakan 6 dari 10 
langkah metode R\&D, yaitu 1) Potensi dan Masalah, 2) Pengumpulan Data, 3) Desain Produk, 4) Validasi Desain, 5) Revisi Desain, dan 6) Uji coba Produk. Hal ini dilakukan karena keterbatasan waktu dalam meneliti.

Potensi pertama yaitu SMAN 1 Gunuang Omeh sudah memiliki akses internet dan komputer untuk membantu proses pembelajaran. Potensi kedua, siswa seharusnya dapat memanfaatkan teknologi untuk menghadapi tantangan di masa depan. Potensi ketiga, siswa seharusnya lebih kreatif dan inovatif.

Setelah diketahui potensi dan masalah, selanjutnya dilakukan pengumpulan informasi. Upaya ini dilakukan untuk mengatasi permasalahan yang ada. Pengumpulan informasi yang dilakukan peneliti dalam rangka mengembangkan produk sumber belajar yaitu bahan ajar yang berbentuk bahan ajar elektronik. Informasi yang dikumpulkan terkait dengan bahan ajar elektronik terintegrasi STEM. Diantara informasi yang dikumpulkan adalah format bahan ajar elektronik yang benar, konsep STEM, energi dan momentum, aplikasi Flip Pdf Professional, dan hasil belajar.

Sebelum digunakan produk divalidasi terlebih dahulu oleh tenaga ahli yaitu dosen fisika FMIPA UNP. Setelah divalidasi produk direvisi sesuai dengan saran para ahli, sehingga produk yang dihasilkan lebih baik dan layak untuk digunakan. Setelah direvisi maka bahan ajar elektronik terintegrasi STEM diuji cobakan di lapangan.

Uji coba produk bertujuan untuk mengetahui efektivitas dari produk melalui uji terbatas. Uji efektivitas dilaksanakan setelah bahan ajar dikategorikan praktis. Uji efektivitas menggunakan eksperimen beforeafter yang dilakukan dalam satu kelas eksperimen dengan membandingkan keadaan sebelum dan sesudah penggunaan bahan ajar seperti yang ditunjukkan pada Gambar 1.

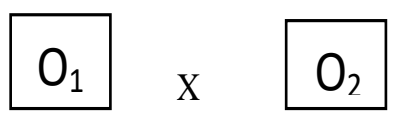

Gambar 1. Desain Sebelum dan Sesudah Penggunaan Bahan Ajar

Berdasarkan Gambar 1, $\mathrm{O}_{1}$ adalah nilai siswa sebelum menggunakan bahan ajar elektronik fisika terintegrasi STEM menggunakan Flip Pdf Professional, sedangkan $\mathrm{O}_{2}$ adalah nilai siswa sesudah menggunakan bahan ajar elektronik fisika terintegrasi STEM menggunakan Flip Pdf Professional. Eksperimen dilakukan dengan membandingkan antara nilai $\mathrm{O}_{1}$ dan $\mathrm{O}_{2}$. Bahan ajar dikatakan efektif apabila nilai post-test siswa lebih tinggi dari nilai pre-test siswa.

Penelitian harus didasarkan pada sekelompok sumber data atau objek yang bervariasi. Penelitian ini terdiri dari tiga variabel penelitian yaitu variabel bebas, variabel terikat, dan variabel kontrol. Variabel bebas adalah variabel yang mempengaruhi variabel terikat. Variabel bebas dari penelitian ini adalah bahan ajar elektronik terintegrasi STEM. Variabel terikat adalah variabel yang berubah seiring dengan perubahan variabel bebas. Variabel terikat dalam penelitian ini adalah hasil belajar siswa kelas X SMA. Variabel kontrol adalah variabel yang digunakan sebagai salah satu cara untuk mengontrol. Adapun variabel kontrol pada penelitian ini yaitu guru, alokasi waktu, jumlah dan jenis soal yang diujikan, serta penilaian.

Tabel 1. Matriks Penelitian Tahapan Uji Coba Produk

\begin{tabular}{lll}
\hline Judul & Variabel & Sub Variabel \\
\hline Pengembanga & Bahan ajar & Konteks dan \\
n Bahan Ajar & & isi \\
Elektronik & & \\
Energi dan & \\
Momentum & \\
Terintegrasi & & \\
\hline
\end{tabular}




\begin{tabular}{|c|c|c|}
\hline Judul & Variabel & Sub Variabel \\
\hline $\begin{array}{l}\text { STEM Untuk } \\
\text { Meningkatka } \\
\mathrm{n} \quad \text { Hasil } \\
\text { Belajar Siswa } \\
\text { SMA }\end{array}$ & $\begin{array}{l}\text { Hasil belajar } \\
\text { siswa }\end{array}$ & $\begin{array}{l}\text { Sikap, } \\
\text { pengetahuan, } \\
\text { dan } \\
\text { keterampilan }\end{array}$ \\
\hline Sumber Data & $\begin{array}{l}\text { Metode } \\
\text { Penelitian }\end{array}$ & Hipotesis \\
\hline $\begin{array}{l}\text { Hasil belajar } \\
28 \text { orang } \\
\text { siswa kelas X } \\
\text { Mipa }\end{array}$ & $\begin{array}{l}\text { 1.Pendekatan } \\
\text { penelitian } \\
\text { kuantitatif } \\
\text { 2. Instrumen } \\
\text { dalam } \\
\text { pengumpula } \\
\text { n data } \\
\text { a. Lembar } \\
\text { observasi } \\
\text { b.Lembar } \\
\text { tertulis } \\
\text { 3. Analisis } \\
\text { data } \\
\text { a. Statistik } \\
\text { deskriptif } \\
\text { b. Uji } \\
\text { homogenita } \\
\text { s } \\
\text { c. Uji t } \\
\text { Lembar } \\
\text { observasi dan } \\
\text { tertulis }\end{array}$ & $\begin{array}{l}\text { Bagaimana } \\
\text { efektifitas } \\
\text { bahan ajar } \\
\text { elektronik } \\
\text { energi dan } \\
\text { momentum } \\
\text { terintegrasi } \\
\text { STEM dalam } \\
\text { meningkatkan } \\
\text { hasil belajar } \\
\text { pada aspek } \\
\text { sikap, } \\
\text { pengetahuan, } \\
\text { dan } \\
\text { keterampilan } \\
\text { siswa kelas X } \\
\text { Mipa di SMA } \\
\text { Negeri 1 } \\
\text { Gunuang } \\
\text { Omeh? }\end{array}$ \\
\hline
\end{tabular}

\section{HASIL DAN PEMBAHASAN}

Hasil

Hasil penelitian dapat dilihat pada tiga aspek yaitu aspek sikap, pengetahuan, dan keterampilan. Hasil analisis dideskripsikan sebagai berikut.

a. Pengaruh Bahan Ajar Elektronik Terintegrasi STEM Terhadap Aspek Sikap

Penilaian sikap siswa sebelum dan sesudah menggunakan bahan ajar elektronik terintegrasi STEM dilakukan setiap pertemuan dengan menggunakan lembar observasi. Pengamatan sebelum menggunakan bahan ajar elektronik ini dilakukan sebanyak empat kali pertemuan. Sikap yang diamati selama kegiatan pembelajaran menggunakan bahan ajar elektronik terintegrasi STEM diantaranya 1) Disiplin (DS), 2) Percaya diri (PD), 3) Kerja keras (KK), 4) Kerja sama (KS), 5)
Tanggung jawab (TJ), dan 6) Toleransi (TL). Pengamatan sikap yang dilakukan sebelum dan sesudah penggunaan bahan ajar elektronik mengalami signifikan perbedaan pada nilai sikap siswa. Hasil pengamatan sikap sebelum dan setelah menggunakan bahan ajar elektronik dapat dilihat pada Gambar 2.

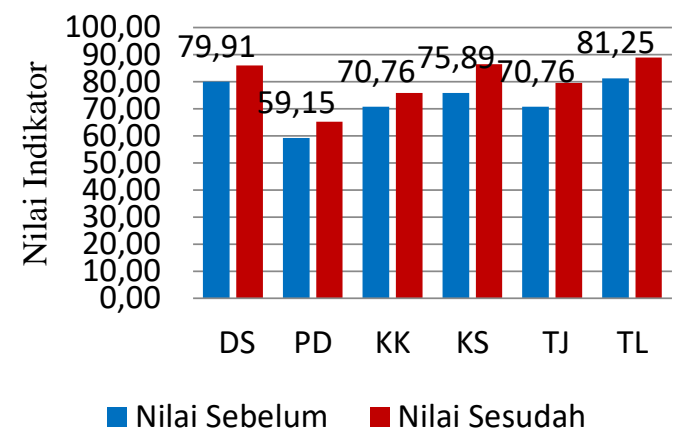

Gambar 2. Nilai Rata-Rata Sikap Siswa Yang Diamati

Bertitik tolak pada Gambar 1 dapat dijelaskan nilai sikap siswa sebelum dan sesudah menggunakan bahan ajar elektronik mengalami peningkatan. Siginifikasi perbedaan nilai sikap siswa sebelum dan sesudah menggunakan bahan ajar elektronik dapat dilihat pada Tabel 2.

Tabel 2. Hasil Analisis Data Aspek Sikap

\begin{tabular}{llll}
\hline No & Statistik & $\begin{array}{l}\text { Nilai } \\
\text { Sebelum }\end{array}$ & $\begin{array}{l}\text { Nilai } \\
\text { Sesudah }\end{array}$ \\
\hline 1 & Rata-rata & 72,95 & 80,28 \\
2 & Standar Deviasi & 6,03 & 6,70 \\
3 & Varians & 36,37 & 44,84 \\
4 & Modus & 65,63 & 72,92 \\
5 & Nilai Lo uji & 0,13 & 0,15 \\
& normalitas & & \\
6 & $\begin{array}{l}\text { Nilai Lt uji } \\
\text { normalitas }\end{array}$ & 0,16 & \\
7 & $\begin{array}{l}\text { Nilai Fh uji } \\
\text { homogenitas }\end{array}$ & 1,23 & \\
8 & $\begin{array}{l}\text { Nilai Ft uji } \\
\text { homogenitas }\end{array}$ & 1,89 & \\
9 & Nilai th & $-13,16$ & \\
10 & Nilai tt & $-1,70$ & \\
\hline
\end{tabular}

Berdasarkan analisis data pada Tabel 1 dapat dijelaskan bahwa terjadi peningkatan pada nilai rata-rata sikap siswa sesudah menggunakan bahan ajar elektronik yaitu 
sebesar 72,95 dan 80,28. Nilai standar deviasi sebelum dan sesudah menggunakan bahan ajar adalah 6,03 dan 6,70. Nilai varians sikap siswa sebelum dan setelah penggunaan bahan ajar adalah 36,37 dan 44,84 .

Data sikap yang telah diperoleh harus diuji normalitas data terlebih dahulu. Hal ini dilakukan untuk melihat apakah kedua data terdistribusi normal. Uji normalitas yang digunakan adalah uji Liliefors. Hasil uji normalitas untuk sikap sebelum dan sesudah menggunakan bahan ajar yang telah dilakukan didapatkan dari harga Lo dan $\mathrm{Lt}$ pada taraf nyata $(\alpha) 0,05$ untuk $n=28$.

Bertitik tolak pada Tabel 1 dapat dijelaskan bahwa nilai dan Lt pada taraf 0,05 dengan jumlah siswa 28 orang. Nilai Lo untuk sikap sebelum adalah 0,13 sedangkan nilai Lo untuk sikap sesudah adalah 0,15. Berdasarkan data yang didapatkan, nilai Lo $<\mathrm{Lt}$, berarti data nilai sikap sebelum dan sesudah penggunaan bahan ajar sama-sama terdistribusi normal.

Setelah dilakukan uji normalitas, maka selanjutnya dilakukan uji homogenitas. Hal ini dilakukan untuk mengetahui data tersebut homogen atau tidak. Hasil uji homogenitas untuk sikap sebelum dan sesudah penggunaan bahan ajar didapatkan dari harga Fh dan Ft. Pada penelitian ini jumlah seluruh siswa adalah 28 orang, sehingga dapat diperoleh besar derajat kebebasannya adalah $\mathrm{dk}=\mathrm{n}-1=28-1=27$. Dari data didapatkan bahwa $\mathrm{Fh}<\mathrm{Ft}$ sehingga data nilai aspek sikap sebelum dan sesudah penggunaan bahan ajar fisika bersifat homogen.

Berdasarkan data tersebut maka data dapat dinyatakan terdistribusi normal dan homogen. Statistik yang digunakan adalah statistik parametrik yaitu uji perbandingan berkorelasi. Perbandingan korelasi berguna untuk membuktikan signifikansi perbedaan sikap siswa sebelum dan sesudah menggunakan bahan ajar elektronik terintegrasi STEM.

Dari analisis dan perhitungan yang telah dilakukan didapatkan nilai t hitung $(\mathrm{t} h)$ yaitu $-13,16$. Harga t tabel (tt) menunjukkan nilai 1,70. Hasil perhitungan th bernilai negatif, maka pada perhitungan dilakukan uji pihak kiri dengan $t t=-1,70$. Pada uji pihak kiri dapat dilihat bahwa nilai th $<\mathrm{tt}$. Nilai th berada pada daerah tolak Ho, hal ini menunjukkan bahwa adanya perbedaan sikap yang signifikan antara sebelum dan sesudah menggunakan bahan ajar elektronik materi energi dan momentum. Jadi, dapat disimpulkan bahwa bahan ajar elektronik fisika materi energi dan momentum efektif digunakan untuk meningkatkan hasil belajar siswa pada aspek sikap siswa.

Tabel 3. Hasil Analisis Data Aspek

\begin{tabular}{|c|c|c|c|}
\hline \multicolumn{4}{|c|}{ Pengetahuan } \\
\hline No & Statistik & $\begin{array}{l}\text { Nilai } \\
\text { Sebelum }\end{array}$ & $\begin{array}{l}\text { Nilai } \\
\text { Sesudah }\end{array}$ \\
\hline 1 & Rata-rata & 45,68 & 67,14 \\
\hline 2 & Standar Deviasi & 10,76 & 12,44 \\
\hline 3 & Varians & 115,75 & 154,51 \\
\hline 4 & Modus & 40,00 & 60,00 \\
\hline 5 & $\begin{array}{l}\text { Nilai Lo uji } \\
\text { normalitas }\end{array}$ & 0,14 & 0,15 \\
\hline 6 & $\begin{array}{l}\text { Nilai Lt uji } \\
\text { normalitas }\end{array}$ & 0,16 & \\
\hline 7 & $\begin{array}{l}\text { Nilai Fh uji } \\
\text { homogenitas }\end{array}$ & 1,33 & \\
\hline 8 & $\begin{array}{l}\text { Nilai Ft uji } \\
\text { homogenitas }\end{array}$ & 1,89 & \\
\hline 9 & Nilai th & $-10,07$ & \\
\hline 10 & Nilai tt & $-1,70$ & \\
\hline
\end{tabular}

Pengaruh bahan ajar elektronik terintegrasi STEM terhadap aspek pengetahuan ditentukan dengan melakukan tes sebelum dan sesudah menggunakan bahan ajar elektronik mengintegrasikan STEM. Soal tes diberikan dalam bentuk soal pilihan ganda dengan menyamakan tingkat kesulitan kisi-kisi soal sebelum dan sesudah menggunakan bahan ajar. Setiap materi diujikan dengan 15 soal untuk 28 siswa dan skor nilai maksimal 100. Data tes sebelum dan sesudah penggunaan bahan ajar 
mengintegrasikan STEM dapat dilihat pada Tabel 3.

Berdasarkan analisis data Tabel 2 dapat dijelaskan bahwa terjadi peningkatan pada nilai rata-rata pengetahuan siswa sebelum dan sesudah menggunakan bahan ajar elektronik terintegrasi STEM yaitu sebesar 45,68 dan 67,14. Nilai standar deviasi sebelum dan sesudah menggunakan bahan ajar elektronik adalah 10,76 dan 12,44. Nilai varians pengetahuan siswa sebelum dan setelah penggunaan bahan ajar adalah 115,75 dan 154,51.

Data pengetahuan yang telah diperoleh harus diuji normalitas data terlebih dahulu. Hal ini dilakukan untuk melihat apakah kedua data terdistribusi normal. Uji normalitas yang digunakan adalah uji Liliefors. Hasil uji normalitas untuk pengetahuan sebelum dan sesudah menggunakan bahan ajar yang telah dilakukan didapatkan dari harga Lo dan Lt pada taraf nyata $(\alpha) 0,05$ untuk $n=28$.

Bertitik tolak pada Tabel 2 dapat dilihat bahwa nilai Lo dan Lt pada taraf 0,05 dengan jumlah siswa 28 orang. Nilai Lo untuk pengetahuan sebelum adalah 0,14 sedangkan nilai Lo untuk pengetahuan sesudah adalah 0,15 . Berdasarkan data yang didapatkan, nilai Lo < Lt, berarti data nilai pengetahuan sebelum dan sesudah penggunaan bahan ajar sama-sama terdistribusi normal.

Setelah dilakukan uji normalitas, maka selanjutnya dilakukan uji homogenitas. Hal ini dilakukan untuk mengetahui data tersebut homogen atau tidak. Hasil uji homogenitas untuk pengetahuan sebelum dan sesudah penggunaan bahan ajar didapatkan dari harga Fh dan Ft. Pada penelitian ini jumlah seluruh siswa adalah 28 orang, sehingga dapat diperoleh besar derajat kebebasannya adalah $\mathrm{dk}=\mathrm{n}-1=28-1=27$. Dari data didapatkan bahwa $\mathrm{Fh}<\mathrm{Ft}$ sehingga data nilai aspek pengetahuan sebelum dan sesudah penggunaan bahan ajar fisika bersifat homogen.

Berdasarkan data tersebut maka data dapat dinyatakan terdistribusi normal dan homogen. Statistik yang digunakan adalah statistik parametrik yaitu uji perbandingan berkorerasi. Perbandingan korelasi berguna untuk membuktikan signifikansi perbedaan pengetahuan siswa sebelum dan sesudah menggunakan bahan ajar elektronik terintegrasi STEM.

Dari analisis dan perhitungan yang telah dilakukan didapatkan nilai t hitung (th) yaitu $-10,07$. Harga $t$ tabel $(t t)$ menunjukkan nilai 1,70. Hasil perhitungan th bernilai negatif, maka pada perhitungan dilakukan uji pihak kiri dengan $t \mathrm{t}=-1,70$. Pada uji pihak kiri dapat dilihat bahwa nilai th $<$ tt. Nilai th berada pada daerah tolak Ho, hal ini menunjukkan bahwa adanya perbedaan pengetahuan yang signifikan antara sebelum dan sesudah menggunakan bahan ajar elektronik materi energi dan momentum. Jadi, dapat disimpulkan bahwa bahan ajar elektronik fisika materi energi dan momentum efektif digunakan untuk meningkatkan hasil belajar siswa pada aspek pengetahuan.

Penilaian bahan ajar elektronik terintegrasi STEM pada aspek keterampilan siswa dilakukan selama proses pembelajaran. Penilaian keterampilan sebelum dan sesudah penggunaan bahan ajar menggunakan lembar instrumen penilaian keterampilan berpikir kreatif untuk melihat keterampilan berpikir kreatif siswa. Indikator penilaian tersebut meliputi 1) mencetuskan banyak ide (MI), 2) menjawab pertanyaan (MP), 3) memberikan cara yang bervariasi (MC), 4) mengajukan pertanyaan yang bervariasi (MT), 5) memberikan gagasan yang baru (MG), 6) memikirkan cara yang tidak lazim (ML), 7) mengembangkan suatu gagasan (MS), dan 8) memperinci secara detail dari suatu ide 
(MD). Data nilai keterampilan sebelum dan setelah menggunakan bahan ajar elektronik dapat dilihat pada Gambar 3.

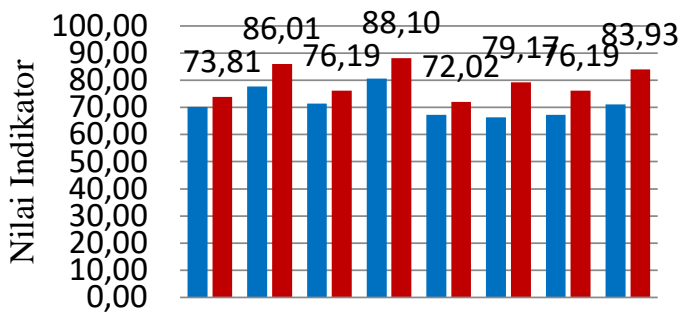

MI MP MC MT MG ML MS MD

Nilai Sebelum Nilai Sesudah

Gambar 3. Nilai Rata-Rata Keterampilan Siswa Yang Diamati.

Bertitik tolak pada Gambar 2 dapat dijelaskan nilai keterampilan siswa sebelum dan sesudah menggunakan bahan ajar elektronik mengalami peningkatan. Siginifikasi perbedaan nilai keterampilan siswa sebelum dan sesudah menggunakan bahan ajar elektronik dapat dilihat pada Tabel 3.

Tabel 4. Hasil Analisis Data Aspek Keterampilan

\begin{tabular}{|c|c|c|c|c|}
\hline No & Statistik & ilai Sebelun & N Nila & ai Sesudah \\
\hline 1 & Rata-rata & 71,50 & & 79,43 \\
\hline 2 & Standar Deviasi & i 7,62 & & 6,29 \\
\hline 3 & Varians & 58,13 & & 39,59 \\
\hline 4 & Modus & 64,58 & & 71,88 \\
\hline 5 & \multicolumn{2}{|c|}{ Nilai Lo uji normalitas } & 0,12 & 0,12 \\
\hline 6 & \multicolumn{2}{|c|}{ Nilai Lt uji normalitas } & 0,16 & \\
\hline 7 & \multicolumn{2}{|c|}{ Nilai Fh uji homogenitas } & 1,47 & \\
\hline 8 & \multicolumn{2}{|c|}{ Nilai Ft uji homogenitas } & 1,89 & \\
\hline 9 & \multicolumn{2}{|c|}{ Nilai th } & $-13,26$ & \\
\hline 10 & \multicolumn{2}{|l|}{ Nilai tt } & $-1,70$ & \\
\hline
\end{tabular}

Berpedoman kepada analisis data Tabel 3 dapat dijelaskan bahwa terjadi peningkatan pada nilai rata-rata keterampilan siswa sebelum dan sesudah menggunakan bahan ajar elektronik terintegrasi STEM yaitu sebesar 45,68 dan 67,14. Nilai standar deviasi sebelum dan sesudah menggunakan bahan ajar adalah 10,76 dan 12,44 . Nilai varians keterampilan siswa sebelum dan setelah penggunaan bahan ajar adalah 115,75 dan 154,51.

Berdasarkan data keterampilan yang telah diperoleh harus diuji normalitas data terlebih dahulu. Hal ini dilakukan untuk melihat apakah kedua data terdistribusi normal. Uji normalitas yang digunakan adalah uji Liliefors. Hasil uji normalitas untuk keterampilan sebelum dan sesudah menggunakan bahan ajar yang telah dilakukan didapatkan dari harga Lo dan Lt pada taraf nyata $(\alpha) 0,05$ untuk $n=28$.

Berdasarkan analisis data pada Tabel 3 dapat dijelaskan bahwa nilai Lo dan Lt pada taraf 0,05 dengan jumlah siswa 28 orang. Nilai Lo untuk keterampilan sebelum adalah 0,12 sedangkan nilai Lo untuk keterampilan sesudah adalah 0,12 . Berdasarkan data yang didapatkan, nilai Lo < Lt, berarti data nilai sikap sebelum dan sesudah penggunaan bahan ajar sama-sama terdistribusi normal.

Setelah dilakukan uji normalitas, maka selanjutnya dilakukan uji homogenitas. Hal ini dilakukan untuk mengetahui data tersebut homogen atau tidak. Hasil uji homogenitas untuk nilai keterampilan sebelum dan sesudah penggunaan bahan ajar didapatkan dari harga Fh dan Ft. Pada penelitian ini jumlah seluruh siswa adalah 28 orang, sehingga dapat diperoleh besar derajat kebebasannya adalah $\mathrm{dk}=\mathrm{n}-1=28-1=27$. Dari data didapatkan bahwa $\mathrm{Fh}<\mathrm{Ft}$ sehingga data nilai aspek keterampilan sebelum dan sesudah penggunaan bahan ajar fisika bersifat homogen.

Berdasarkan analisis data tersebut maka data dapat dinyatakan terdistribusi normal dan homogen. Statistik yang digunakan adalah statistik parametrik yaitu uji perbandingan berkorelasi. Perbandingan korelasi berguna untuk membuktikan signifikansi perbedaan keterampilan siswa sebelum dan sesudah menggunakan bahan ajar elektronik terintegrasi STEM. 
Berdasarkan analisis dan perhitungan yang telah dilakukan didapatkan nilai $\mathrm{t}$ hitung (th) yaitu $-13,26$. Harga $t$ tabel (tt) menunjukkan nilai 1,70. Hasil perhitungan th bernilai negatif, maka pada perhitungan dilakukan uji pihak kiri dengan $\mathrm{tt}=-1,70$. Pada uji pihak kiri dapat dilihat bahwa nilai th $<$ tt. Nilai th berada pada daerah tolak Ho, hal ini menunjukkan bahwa adanya perbedaan pengetahuan yang signifikan antara sebelum dan sesudah menggunakan bahan ajar elektronik materi energi dan momentum. Jadi, dapat disimpulkan bahwa bahan ajar elektronik fisika materi energi dan momentum efektif digunakan untuk meningkatkan hasil belajar siswa pada aspek keterampilan.

\section{Pembahasan}

Hasil penelitian menunjukkan bahan ajar elektronik terintegrasi STEM ini efektif digunakan dalam pembelajaran fisika. Hal ini terlihat dari analisis uji efektivitas seperti uji efektivitas aspek sikap, pengetahuan, dan keterampilan. Dari hasil analisis uji efektivitas dapat dilihat bahwa adanya perbedaan signifikan sebelum dan sesudah menggunakan bahan ajar elektronik materi energi dan momentum.

Hasil efektivitas dari bahan ajar elektronik sesuai dengan teori, bahan ajar merupakan salah satu sumber belajar yang dapat dimanfaatkan oleh siswa sehingga pembelajaran lebih efektif dan interaktif (Nana, 2019). Bahan ajar Fisika berbasis STEM memberikan pengaruh yang efektif terhadap hasil belajar pada aspek sikap, pengetahuan, dan keterampilan (Izzah, N., Asrizal, \& Festiyed, 2021)

Peningkatan yang signifikan terhadap hasil belajar siswa dapat terjadi karena pembelajaran fisika dalam penelitian ini dibantu dengan bahan ajar elektronik terintegrasi STEM. Pembelajaran yang dikaitkan dengan aspek-aspek STEM memberikan kesempatan kepada siswa untuk memahami konsep fisika dipadukan dengan teknologi, engineering, dan matematika melalui kegiatan diskusi, praktikum, dan kegiatan proyek. Kegiatan yang dilakukan selama proses pembelajaran tersebut dapat meningkatkan minat siswa sehingga meningkatkan hasil belajar siswa (Pangesti, Yulianti, \& Sugianto, 2017).

Hasil belajar siswa mencakup aspek sikap, pengetahuan, dan keterampilan (Kemendikbud, 2016). Aspek sikap yang dinilai yaitu disiplin, percaya diri, kerja keras, kerja sama, tanggung jawab, dan toleransi. Berdasarkan observasi sikap yang telah dilakukan terdapat peningkatan nilai sikap siswa setelah menggunakan bahan ajar elektronik terintegrasi STEM.

Aspek pengetahuan penggunaan bahan ajar terintegrasi STEM dapat meningkatkan pemahaman konsep siswa yang ditandai dengan peningkatan pretest dan posttest siswa (Pangesti, Yulianti, \& Sugianto, 2017). Tes merupakan alat yang digunakan untuk mengukur pengetahuan (Djaali, 2020). Hasil efektifitas aspek pengetahuan siswa sebelum dan setelah menggunakan bahan ajar elektronik terintegrasi STEM menunjukkan terdapat peningkatan hasil belajar siswa setelah menggunakan bahan ajar terintegrasi STEM.

Aspek keterampilan yang diamati yaitu keterampilan berpikir kreatif. Indikator keterampilan berpikir kreatif meliputi 1) mencetuskan banyak ide (MI), 2) menjawab pertanyaan (MP), 3) memberikan cara yang bervariasi (MC), 4) mengajukan pertanyaan yang bervariasi (MT), 5) memberikan gagasan yang baru (MG), 6) memikirkan cara yang tidak lazim (ML), 7) mengembangkan suatu gagasan (MS), dan 8) memperinci secara detail dari suatu ide (MD) (Utami., Endaryono, \& Djuhartono, 2020). Berdasarkan hasil observasi keterampilan berpikir kreatif siswa sebelum dan setelah 
menggunakan bahan ajar terdapat peningkatan hasil belajar siswa pada aspek keterampilan setelah menggunakan bahan ajar elektronik terintegrasi STEM.

Pada saat pelaksanaan penelitian yang dilakukan terdapat berbagai kendala dan keterbatasan. Keterbatasan pertama adalah bahan ajar yang dibuat masih dalam $2 \mathrm{KD}$ materi kelas X. Hal ini disebabkan karena keterbatasan waktu peneliti dalam mengembangkan bahan ajar.

Tindak lanjut dari penelitian ini kedepannya bahan ajar elektronik dapat dibuat untuk semua materi yang terdapat di kelas $\mathrm{X}$ agar menghasilkan bahan ajar elektronik yang lebih lengkap. Keterbatasan yang kedua adalah uji coba produk hanya pada satu kelas eksperimen. Solusi yang diberikan adalah bahan ajar diuji cobakan dalam skala luas. Keterbatasan yang ketiga adalah keterbatasan pelaksanaan kegiatan eksperimen. Hal ini disebabkan karena keterbatasan waktu peneliti. Solusi yang diberikan uji coba bahan ajar kedepannya dilakukan lebih efektif dan efisien.

\section{PENUTUP}

Penggunaan bahan ajar elektronik materi energi dan momentum terintegrasi STEM menggunakan Flip Pdf Professional untuk meningkatkan hasil belajar siswa efektif digunakan untuk meningkatkan hasil belajar siswa pada aspek sikap, pengetahuan, dan keterampilan.

\section{REFERENSI}

Asrizal, Festiyed, dan Sumarmin, R. (2017). Analisis Kebutuhan Pengembangan Bahan Ajar IPA Terpadu Bermuatan Literasi Era Digital Untuk Pembelajaran Siswa SMP Kelas VIII. Jurnal Eksakta Pendidikan (JEP), $1,7$.

Britain, G. (2012). Higher Education in Science, Technology, Engineering, and Mathematics (STEM) Subjects. London: House of Lords.

Capraro, R.M. dan Morhan, J. (2013). STEM Project-Based Learning: An Integrated Science, Technology, Engineering, and Mathematics (STEM) Approach. Rotterdam: Sense Publishers.

Djaali. (2020). Metodologi Penelitian Kuantitatif. Jakarta: PT Bumi Aksara.

Fitria, Y \& Idriyeni. (2017). Development of Problem-Based Teaching Materials for. Jurnal Ta'dib, 20(2), 99.

Hustarna, H \& Melati, M. (2019). Developing A Teaching Material Prototype for Linguistics Description of English Course. International Journal of Language Teaching and Education, 3(1), 1.

Izzah, N., Asrizal, \& Festiyed. (2021). Meta Analisis Effect Size Pengaruh Bahan Ajar IPA dan Fisika Berbasis STEM Terhadap Hasil Belajar Siswa. Jurnal Pendidikan Fisika FKIP UM Metro, 9, 125.

Izzati, N., Tambunan, L. R., Susanti, S., and Siregar, N. A. R. (2019). Pengenalan Pendekatan STEM sebagai Inovasi Pembelajaran Era Revolusi Industri 4.0. Jurnal Anugrah, 1(2), 83-84.

Kelana, J. B. \& Pratama, D. (2019). Bahan Ajar IPA Berbasis Litersi Sains. Bandung: LEKKAS.

Kemendikbud. (2016). Permendikbud Nomor 23 tahun 2016 Tentang Standar Penilaian Pendidikan. Jakarta: Depdiknas.

Kustijono, H \& Watin, R. (2017). Efektivitas penggunaan E-book dengan Flip PDF Professional untuk Melatihkan Keterampilan Proses Sains. SEMINAR NASIONAL FISIKA $(S N F)$ (p. 127). Surabaya: SNF Jurusan Fisika FMIPA UNES.

Lestari, D. A. B., Astuti, B., \& Darsono, T. (2018). Implementasi LKS dengan 
Pendekatan STEM (Science,

Technology, Engineering, and Mathematics) Untuk Meningkatkan Kemampuan Berpikir Siswa. Jurnal Pendidikan Fisika dan Teknologi, 4, 202.

Lin, M. H., Chen, H. C., and Liu, K.S. (2017). A Study of the Effects of Digital Learning on Learning Motivation and Learning Outcome. EURASIA Journal of Mathematics Science and Technology Education, 13(7), 3554.

Mirdanda, A. (2018). Motivasi Berprestasi \& Disiplin Peserta Didik Serta Hubungannya dengan Hasil Belajar. Pontianak: Yudha English Gallery.

Mustafa, N., Zaleha, I, Tasir, Z., and Said, M. N. H. M. (2016). A MetaAnalysis on Effective Strategies for Integrated STEM Education. American Scientific Publisher, 12, 4425.

Nana. (2019). Pengembangan Bahan Ajar. Klaten: Lakeisha.

NRC. (2014). STEM Integration in K-12 Education: Status, Prospects, and An Agenda for Research. Washington, DC: The National Academies of Science.

Pangesti, K.I., Yulianti, D and Sugianto. (2017). Bahan Ajar Berbasis STEM (Science, Technology, Engineering, and Mathematics) untuk Meningkatkan Penguasaan Konsep Siswa SMA. Unnes Physics Education Journal, 57.

Ramdani, S. D., Islami, R. A. Z. E., Pratiwi, H., Fawaid, M., Abizar, H., \& Maulani, I. (2021). Developing digital teaching material on basic electricity based on problem-based learning in vocational education. 11(1), 78 .

Riwu, I. U., Laksana, D. N. L., and Dhiu, K. D. (2018). Pengembangan Bahan Ajar Elektronik Bermuatan Multimedia Pada Tema Peduli
Terhadap Makhluk Hidup Untuk Siswa Sekolah Dasar Kelas IV di Kabupaten Ngada. Jurnal Of Education Technology, 2, 57.

Roehrig, G. H., Dare, E. A., Whalen, E. R., and Wieselmann, J. R. . (2021). Understanding coherence and integration. International Journal of, 2.

Seruni, R., Munawaoh, S., Kurniadewi, F., and Nurjayadi, M . (2019). Pengembangan Modul Elektronik (E-Modul) Biokimia Pada Materi Metabolisme Lipid Menggunakan Flip Pdf Professional. Jurnal Tadris Kimiya, 50.

Simmarmata, J., Simanhuruk, L., Ramadhani, R., Safitri, M., Wahyuni, D., and Iskandar, A. (2020). Pembelajaran STEM Berbasis HOTS dan Penerapannya. Medan: Yayasan Kita Menulis.

Singgih, S., Dewantari, N., \& Suryandari. (2020). STEM dalam Pembelajaran IPA di Era Revolusi Industri 4.0. Indonesia Journal of Natural Science Education. Indonesia Journal of Natural Science Education (IJNSE), 03, 300 .

Sriwahyuni, I., Risdianto, E., \& Johan, H. (2019). Pengembangan Bahan Ajar Elektronik Menggunakan Flip Pdf Professional pada Materi Alat-Alat Optik di SMA. Jurnal Kumparan Fisika, 2(3), 146.

Sugiyono. (2012). Metode Penelitian Kuantitatif Kualitatif dan $R \& D$. Bandung: ALFABETA.

Utami, R. W., Endaryono, B. T., dan Djuhartono, T. (2020). Meningkatkan Kemampuan Berpikir Kreatif Matematis Siswa Melalui Pendekatan Open-Ended. Faktor Jurnal Ilmiah Kependidikan, 2, 4546.

Wahano, B. , Lin, P L., and Chang, C. Y. (2020). Evidence of STEM Enactment Effectiveness in Asian 
Student Learning Outcomes.

International Journal of STEM Education, 15.

Wibowo, E \& Pratiwi, D. D. (2018). Pengembangan Bahan Ajar Menggunakan Aplikasi Kvisoft Flipbook Maker. Jurnal Matematika, 148.

Winarni, J., Zubaidah, S., \& Supriyono, K. H. (2016). STEM: Apa, Mengapa, dan Bagaimana. (p. 978). Pros. Semnas Pendidikan IPA Pascasarjana UM.

Yata, C., Ohtani, T., \& Isobe, M. (2020). Conceptual Framework of STEM Based on Japanese Subject Principles. International Journal of STEM Education. 